DOI: $10.14746 /$ pi.2021.13.3

\title{
Nie nekrolog, lecz brak (ten, co się zemści)
}

\section{|Katarzyna Kuczyńska-Koschany}

Zmarła Maria Janion, 23 sierpnia 2020 - w Warszawie.

Dzięki profesor Marii Janion, najwybitniejszej polskiej literaturoznawczyni, dane mi było zrozumieć - pierwszy raz - kim jest wielki człowiek, wielka osobowość twórcza. Zrozumieć, co znaczy topos karłów na ramionach olbrzymów (i do czego zobowiązuje). Najpierw zrozumieć, gdy czytałam jej porywające eseje, szkice, artykuły, książki - właśnie, porywające, pełne żaru, a przecież rzetelne, wynikające $\mathrm{z}$ fenomenalnego oczytania. Potem zrozumieć jeszcze bardziej, kiedy - zaproszona przez Panią Profesor - mogłam (co przechodziło moje najśmielsze marzenia, jako kogoś, kto dopiero napisał doktorat) się z Nią spotkać, 14 lipca 2005 roku, w mieszkaniu, zbudowanym wyłącznie z książek. Wreszcie, kiedy rozmawiałyśmy, wznosiłyśmy toast (wodą) za rewolucję francuską, kiedy dotknęłam rękopisu 18-letniej wilnianki (kaligraficzne, przedwojenne pismo), spolszczającej - w samym środku wojny z Niemcami - Korneta Rilkego, kupionego zresztą w księgarni „nur für Deutsche”. Z podobną konsekwencją wyciągała książki Ernsta Jüngera ze stosów palonych po wojnie niemieckojęzycznych książek. Słuchałam opowieści. Rozmawiałyśmy, a ja nie czułam, że rozmawiam z tą wspaniałą, uważną i surową osobą - pierwszy raz. Potem jeszcze dwa razy zjechała ze mną profesor Janion windą i dwa razy wjechała, żeby pokazać mi, że nic złego się nie stanie (nie jeździłam wówczas windą - po urazie z dzieciństwa). Gdy pisała o humanistyce jako poznaniu i terapii - wtedy znów zrozumiałam - to nie były czcze słowa; kiedy ktoś potrzebował pomocy (nawet w tak, zdawać by się mogło, błahej sprawie) Maria Janion wiedziała, że potrzebuje jej natychmiast. Jako matka sześcioletniego syna, Tobiasza, marzyłam wtedy, by mieć córkę. Usłyszałam od Pani Profesor, że na pewno tak się stanie. I rzeczywiście, 27 września 2006 roku, rok po wizycie u autorki Goraczki romantycznej, urodziła się Lena Miriam. 
Maria Janion. Wielka Uczona, wielka Wiedźma (w najlepszym, feministycznym tego słowa znaczeniu). Kilkugodzinną rozmowę z Nią traktuję jako jedno z najważniejszych spotkań w moim życiu; w życiu naukowym - jako bezspornie najważniejsze. Myślę, że wraz ze śmiercią Marii Janion, skończyła się pewna epoka: już nowoczesnego czytania literatury, jeszcze prawdziwej filologii; już - zadawania pytań wcześniej niewyobrażalnych, niestosownych, niebywale odważnych, jeszcze - niekłamanej erudycji. 